Digitized by the Internet Archive in 2011 with funding from

LYRASIS members and Sloan Foundation

http://www.archive.org/details/mosquitosurveyat00butt 


\section{CONNECTICUT}

\section{AgRICULTURAL EXPERIMENT STATION}

NEW HAVEN, CONN.

\section{BULLETIN 189, DECEMBER, 1915}

\section{A MOSQUITO SURVEY AT THE MOUTH OF THE CONNECTICUT RIVER}

Made under the Direction of W. E. Britton, Ph.D.

State and Station Entomologist

BY

P. L. Butroick, Special Agent of the Station

The expense of making this Survey and of printing this report was met by

The Old Saybrook Town Improvement Association of Old Saybrook.

The Bulletins of this Station are mailed free to citizens of Connecticut who apply for them, and to others as far as the editions permit. 


\section{CONNECTICUT AGRICULTURAL EXPERIMENT STATION. OFFICERS AND STAFF.}

\section{BOARD OF CONTROL}

His Excellency, Marcus H. Holcomb, ex-officio, President.

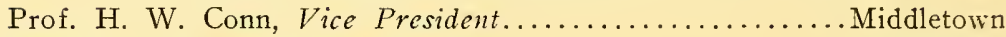
George A. Hopson, Secretary..................Wallingford E. H. Jenkins, Director and Treasurer.................. Hew Haven

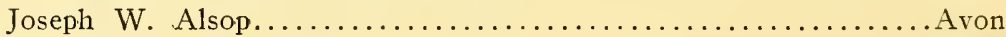

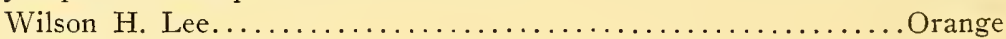
Frank H. Stadtmueller............................ Elmwood

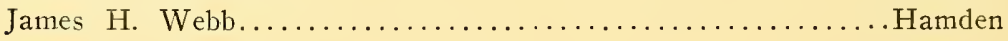

Administration. E. H. Jenkins, Рн.D., Director and Treasurer. Miss V. E. CoLe, Librarian and Stenographer. Miss L. M. Brautlecht, Bookkeeper and Stenographer.

Chemistry. William VeItch, In charge of Buildings and Grounds.

Analytical Laboratory. John Phillips Street, M.S., Chemist in Charge.

E. Monroe Bailey, Ph.D., C. B. Morison, B.S.

C. E. Shepard, G. L. Davis, Assistants.

Hugo Lange, Laboratory Helper.

V. L. Churchill, Sampling Agent.

Miss E. B. Whittlesey, Stenograplect.

Proteid Research. T. B. Osborne, Рн.D., Chemist in Chargc. Miss E. L. FERry, M.S., Assistant.

Potany.

G. P. Clinton, Sc.D., Botanist.

E. M. Stoddard, B.S., Assistant Botanist.

Miss E. B. Whittlesey, Herbarium Assistant.

G. E. Graham, General Assistant.

Entomology.

W. E. Britton, Pн.D., Entomologist; State Entomologist.

B. H. Walden, B.Agr., First Assistant.

Q. S. Lowry, B.Sc., I. W. Davis, B.Sc., \}Assistants.

Miss G. A. Foote, B.A., Stenographer.

Forestry.

Walter O. Filley, Forester; also Statc Forestcr and State Forest Firc II arden.

A. E. Moss, M.F., Assistant Station Forester.

Miss E. L. Avery, Stenographer.

Plant Breeding.

Donald F. Jones, B.S., Plant Brecder.

C. D. HuвBeLL, Assistant.

Vegetable Growing. Howard F. HubER, B.S. 


\section{TABLE OF CONTENTS.}

Introduction $\ldots \ldots \ldots \ldots \ldots \ldots \ldots \ldots \ldots \ldots \ldots \ldots \ldots \ldots \ldots \ldots \ldots, \quad 5$

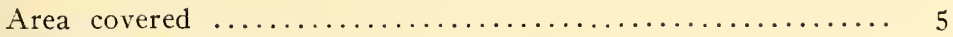

General Observations ............................. 5

Observations on Mosquito Breeding ..................... 7

Life History of the Salt Marsh Mosquito ................. 7

Effects of the Tides $\ldots \ldots \ldots \ldots \ldots \ldots \ldots \ldots \ldots \ldots \ldots \ldots \ldots \ldots, 7$

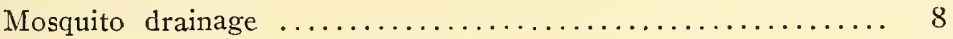

Maintenance of Drainage Ditches .................... 8

Classification of Areas According to Mosquito-breeding Conditions 9

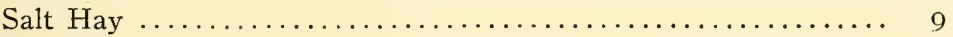

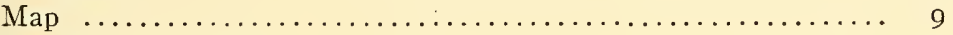

Estimates of Cost $\ldots \ldots \ldots \ldots \ldots \ldots \ldots \ldots \ldots \ldots \ldots \ldots$,

Summary of Costs $\ldots \ldots \ldots \ldots \ldots \ldots \ldots \ldots \ldots \ldots \ldots \ldots$ II

Notes on Township of Old Saybrook $\ldots \ldots \ldots \ldots \ldots \ldots \ldots \ldots \ldots$ I2

Introduction $\ldots \ldots \ldots \ldots \ldots \ldots \ldots \ldots \ldots \ldots \ldots \ldots \ldots \ldots \ldots \ldots \ldots$, I2

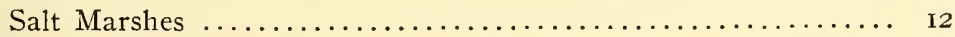

Detailed Description of Individual Salt Marsh Areas ......... I3

Chalker Beach and Chapman's Point Marshes ............. I4

Oyster River Marsh ............................. I4

Back River and Plum Bank Creek Marshes ............ I5

South Cove and Fenwick Point Marshes .............. I6

North Cove and Church House Marshes .............. is

Marshes north of Railroad Line $\ldots \ldots \ldots \ldots \ldots \ldots \ldots \ldots$. 19

Fresh Water Breeding Areas $\ldots \ldots \ldots \ldots \ldots \ldots \ldots \ldots \ldots \ldots$. 19

Malarial Breeding Places ....................... 19

Advisability of Controlling Fresh Water Breeding Places .. 20

Kinds of Fresh Water Breeding Places ................ 20

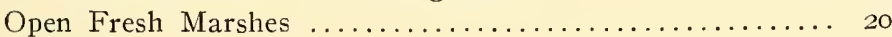

Wooded Marshes .............................. 20

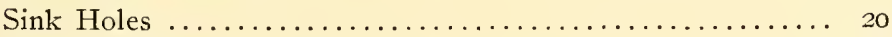

Edges of Sluggish Streams ..................... 20

Description of Individual Fresh Water Breeding Places .... 2I

Summary of Costs for Saybrook ...................... 23

Notes on Townships of Lyme and Old Lyme $\ldots \ldots \ldots \ldots \ldots \ldots . \ldots . \ldots . \ldots 23$

Detailed Descriptions ............................ 24

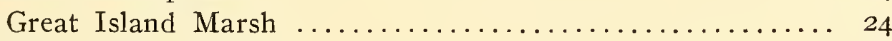

Back River Marshes ........................... 25

Lieutenant River Marsh $\ldots \ldots \ldots \ldots \ldots \ldots \ldots \ldots \ldots \ldots . \ldots \ldots$

Up-River Marshes ........................... 26

Duck River and Black Hall Marshes ................. 26

Black Hall River Marshes ........................ 28

Shore Marshes .................................. 30

Summary of Costs for Lyme ....................... 3I 


\section{Prefatory Note.}

The Director of the Connecticut Agricultural Station is authorized by law to make rules and orders regarding the elimination of mosquitoes and personally or by his agent to enter premises for inspection and to survey and to eliminate by drainage, filling or otherwise treating mosquito-breeding areas. Due notice of the proposed plan of elimination must be given by him, and any one claiming to be aggrieved by the proposed operations may appeal to the Superior Court.

No funds are provided by the State for the purposes of this act and therefore the work of mosquito elimination can be undertaken only at the expense of individuals or local organizations.

The following survey was made at the request and at the expense of The Old Saybrook Town Improvement Association. Dr. W. E. Britton, the State and Station Entomologist, who has had years of experience and study of the mosquito problem in this State, was given the general superintendence of the matter and the survey itself was made by Mr. P. L. Buttrick. Mr. Buttrick has made a number of mosquito surveys in other parts of the State and the principles of work and form of the present survey will have interest and value to other communities which are considering the elimination of mosquitoes. The object of such a survey is to ascertain the location and character of mosquito-breeding places, to determine how they can best be eliminated and to roughly estimate the probable cost. It is believed that this survey, with the accompanying map, makes it possible for those interested to decide what work is most necessary, where money can best be spent and the approximate cost of any portion or of all the work.

E. H. Jenkins, Director. 


\title{
REPORT ON A MOSQUITO SURVEY AT THE MOUTH OF THE CONNECTICUT RIVER
}

\author{
By P. L. Buttrick, Special Agent
}

OF THE

\section{Connecticut Agricultural Experiment Station \\ New Haven, Conn.}

\section{AUGUST-SEPTEMBER, 1915}

\section{INTRODUCTION.}

Area Covered. This survey covers all the salt and brackish marshes in the townships of Old Saybrook and Old Lyme, together with portions of those in Essex and Lyme. Particular attention has been given to the marshes bordering the river. Fresh marshes and other mosquito-breeding places have been included where it seemed that they were of sufficient importance to warrant it. In many cases the notes on fresh water areas are not as complete as those on the salt marsh areas. The notes for the towns on opposite sides of the river are given separately. In Saybrook the notes on salt and fresh water areas are separated; in Lyme this was impracticable though when possible the estimates are given separately.

General Observations on Salt Marshes. The region of this survey contains probably the largest group of salt marshes in the state east of New Haven. The total area of salt and brackish marshes is:

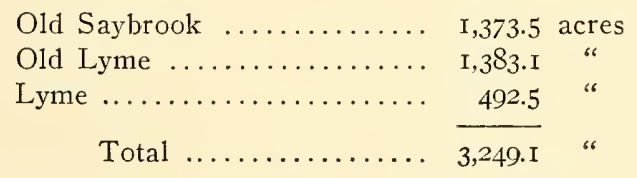

These marshes vary in character in proportion to the amount of submergence which they undergo by action of the tide. There are at least four classes as follows: 
Areas covered with wild rice (Zizania aquatica) and vegetation of like nature which are flooded either constantly or at every high tide. They are known as tidal flats and do not breed mosquitoes. No areas of this class are shown on the accompanying map.

The next class includes the so-called sedge grass marshes which are quite generally flooded at perigee and apogee tides and upon which water frequently stands for a considerable time thereafter. Marshes of this character are inveterate mosquito breeders. The vegetation upon them, although sometimes cut for hay, is generally of inferior value.

Marshes less frequently flooded and standing at a higher level than those just mentioned constitute the next class. They are generally covered with hay grasses of various kinds, the most common of which are popularly called black grass (Juncus gerardi) and red top, or red salt grass (Spartina patens, formerly known as $S$. juncea). These marshes breed mosquitoes more or less, but only under very exceptional conditions do they breed them as abundantly as the preceding.

As the marsh stretches further and further back from the shore it is less frequently flooded by salt water and more frequently by fresh water. This change shows in the vegetation, which is usually composed either of a sedge called 3 -square, (Scirpus), from the triangular shape of its stems; or of cat-tails. Such areas vary from brackish to entirely fresh, but when the latter stage is reached, the nature of this herbage changes to that of some of the types of purely fresh marshes. Marshes of this type are casual breeding places, sometimes breeding both salt and fresh water mosquitoes. The borders of many of the marshes, particularly on the Lyme side of the river, consist of tidal flats.

The Sound marshes, particularly on the Saybrook side, are mostly of the second or sedge grass type and the same is true of those at the mouth of Black Hall River and on South Cove, and it is upon them that the worst mosquito breeding takes place. Further back most of the marshes are of the hay grass type. Above the railroad bridge they become less and less salt in character and finally above Essex the salt marsh entirely disappears. 
Along the Sound shore of Lyme conditions are somewhat different. Here the tidal current sweeps in from the east and the heavy east winds which blow from the open Atlantic have piled up the sands along the shore and partly or completely blocked the marsh drainage, turning many salt marshes into fresh ones without outlets, or into brackish ones with only occasional outlets. As far as mosquito breeding is concerned, these factors have produced rather special conditions which will be discussed later.

Observations on Mosquito Breeding. No attempt was made to identify all the species of mosquitoes found. They were grouped into the general classes of salt marsh species, fresh water species, and malarial species. The most common mosquito is the ordinary banded Salt Marsh Mosquito (Aëdes sollicitans, Walker), which breeds in flood pools wherever they occur on the salt marshes. This species was found breeding under somewhat unusual conditions far up the river above the area of salt marshes, both in drainage ditches on Nott's Island, which is a reclaimed fresh marsh, and in a mud puddle in the road on the edge of the Essex marsh just up stream from the second Range Light. At the edges of salt marshes and along the river, where owing to the influx of fresh water the saline content was light, salt and fresh water mosquitoes were apparently breeding in the same pools.

Concerning the fresh water breeding perhaps the most noteworthy feature is the presence of numerous sink holes which form ideal Anopheles breeding places.

Life History of Salt Marsh Mosquito. In order to understand the mosquito problem on salt marshes, some knowledge of the life history of the salt marsh mosquito is necessary. The eggs are laid upon the salt marsh mud, and not, as with most species of mosquitoes, on the surface of the water. When covered with water they hatch, and in about a week, in warm weather, the adults are ready to fly. They then invade the uplands, often flying in large numbers for many miles. The salt marshes are covered periodically by high tides and irregularly by heavy rains.

Effects of the Tides. Generally speaking, the breeding of the salt marsh mosquito is much more affected by the tides than by rainfall. Under typical conditions the marshes are flooded 
once or twice a month at perigee and apogee, and definite broods of mosquitoes are produced once or twice a month in consequence and can be predicted in advance. This is the condition on marshes along streams emptying directly into the Sound, particularly at Saybrook; but on marshes along the river this condition is complicated by the rise and fall of the river due to local or more often upstream rainfall, so that it is impossible accurately to predict the time of flooding and the resulting appearance of mosquito broods. In fact, flooding at irregular intervals by fresh water is the normal condition on the up-river marshes, so that in dry seasons they probably breed sparingly if at all, and in wet seasons moderately but continuously. Above the railroad bridge the influence of tides on mosquito breeding grows less and at Essex and beyond it is negligible.

Mosquito Drainage. In order to prevent the breeding of the salt marsh mosquito it is only necessary to prevent flood water from standing on the marshes. This is generally accomplished by putting in a system of ditches which allows water to drain off within a few hours after the marsh is flooded by tides or rainfall. Such a system requires a good clear outlet and a main drainage course of dimensions suited to the size of the area.

A system of parallel ditches from to to I 8 inches wide and from 24 to 36 inches deep should be cut at distances varying from Ioo to 300 feet apart, at right angles to this main course.

Most of the marshes at Lyme and Saybrook have main drainage courses which can be used as a groundwork for ditching systems, although in some cases it will be necessary to modify or supplement them. There are also many old ditches which if cleaned can be incorporated as part of the new system.

Maintenance of Drainage Ditches. Deep straight-sided ditches such as are used for mosquito drainage will last almost indefinitely if they are kept open and in working order. They should be thoroughly cleaned every year, in the spring, and it is advisable to have them patrolled during the breeding season and any casual obstructions removed. Occasional breeding spots can also be treated when discovered. In all probability it will require two inspectors to do this patrol work and assist and supervise the annual cleaning operation. One inspector should be assigned to each town. The cost of such cleaning and inspection should not exceed \$I,000.00 per annum. 
According to a recent law passed by the Legislature, towns are obliged to maintain such ditches if the plan and execution of the work are duly approved by the Director of the Agricultural Experiment Station.

Salt Hay. Formerly the marshes of Lyme and Saybrook were regarded as of more value than at present as sources of salt hay and were ditched frequently so as to allow tide water to drain off as this increases the hay yield and improves its quality. Some of the meadows are still ditched for this purpose but on many of them the ditches are no longer maintained.

This ditching of hay land operates to prevent mosquito breeding and there are few mosquitoes breeding on the areas so treated. On the other hand, ditching to eliminate mosquitoes improves the hay yield. If all marshes were ditched to increase the hay yield there would be few mosquitoes, or if all were ditched to prevent mosquito breeding there would be a vastly increased hay yield.

Map. The map submitted with this report shows all the salt marshes examined and most of them very accurately. A few dotted areas were mapped in roughly in the field as the base map did not cover them. This map shows the larger ditches and drainage channels and in some cases the proposed location of new main ditches, but it does not show the location of proposed small ditches as those can as well be laid out in the field and would scarcely show on the map owing to its reduced scale. Each area which forms a unit has been assigned a number which is placed upon the map. A description of the area will be found by reference to the same number in the notes. Those on the Saybrook side refer to that town and to Essex; those on the opposite side to Lyme and Old Lyme. A cross indicates a bad breeding place or point requiring special consideration. The charts of the U. S. Coast and Geodetic Survey were used as a base map.

\section{Classification of Areas According to Mosquito-breeding Conditions.}

In order to bring out clearly the breeding conditions and relative importance of the different marsh areas they have been divided into five groups on the basis of their breeding character, and each group is colored differently on the map.

Following is a description of these different groups: 
A. Low sodden marshes, flooded at every perigee and apogee tide period, and at many intermediate ones. This water remains long enough for all mosquito larvae to complete their development. Such areas respond quickly to rainfall and may produce added broods because of it. Such marshes are almost constant mosquito breeders and yield little salt hay. They are colored brown on the accompanying map.

B. High tide grass breeding marshes. Marshes of this kind have large areas covered with certain grasses or sedges where water stands long enough twice each month, following perigee and apogee tides, for mosquitoes to develop. In other portions mosquito breeding may occur only at perigee tides. It is the areas of Class B that give rise to the immense broods which occur only once or twice in a season. In discussing the different areas of this type of marsh an attempt has been made to give an estimate of the percentage of the total area which remains water-covered long enough to breed mosquitoes. Hay yields on this type of meadow are apt to be small. Areas of this character are colored onflon the map.

C. Marshes covered with open or grassy pools in which mosquitoes breed abundantly. In this class of marsh the general surface may or may not be capable of breeding mosquitoes, so in the descriptions it is sometimes necessary to resort to other classifications in addition to this one. The hay yield may be good, but the broken character of the surface renders it difficult to cut. Marsh of this character is colored red on the accompanying map.

D. Marshes on which mosquitoes breed occasionally and scatteringly, either in grass or pools. Generally these are fair or good hay producers. They are colored green on the map.

E. Marshes which breed only casually or rarely and only in small amounts, generally in small pools along their inner edges, or perhaps in clogged ditches. Marshes of this type are generally either tidal or are high and well drained. The latter are valuable for salt hay, the former seldom so. This type of marsh is colored yellow on the map.

Estimate of Cost of Ditching and other Work Necessary to Eliminate Mosquito Breeding. One object of this survey was of course to arrive at the probable cost of treating the marshes 
so as to prevent mosquito breeding. In preparing this estimate the following factors were considered for each area:

Amount of old ditch to be cleaned;

Footage of lateral $\mathrm{IO}^{\prime \prime}$ x $30^{\prime \prime}$ ditch to be excavated ;

Footage of secondary outlet, generally $2^{\prime} \times 3^{\prime}$ ditches required;

Footage of primary ditches of larger dimensions required;

Amount of special work, such as building and enlarging culverts, erecting tide gates, bulkheads, etc.

The cost of each was then estimated, in the case of ditch digging by applying a footage rate; in the case of cleaning old ditches and doing other work by figuring roughly the amount of labor and materials required. The footage rate for $\mathrm{ro}^{\prime \prime} \times 30^{\prime \prime}$ lateral ditches is taken as $2^{\mathrm{T}} / 2$ cents per foot; for $2^{\prime} \times 3^{\prime}$ secondary ditching 5 cents per foot is used. For larger ditches special rates have been used and specified. Likewise special rates for the different fresh water areas have been made to meet their special conditions.

\section{Summary of Costs.}

It should cost roughly $\$ 19,000.00$ to eliminate all the salt marsh and more important fresh water breeding areas in the region of this survey. But $\$ \mathrm{I}_{5}, 000.00$ spent on the salt marshes should be sufficient for them, while $\$ 2,000.00$ spent on the important fresh water areas should suffice for all practical purposes. Total $\$ 17,000.00$.

Following is a summary of the amount of ditching and costs in round figures:

AREA SALT MARSHES.

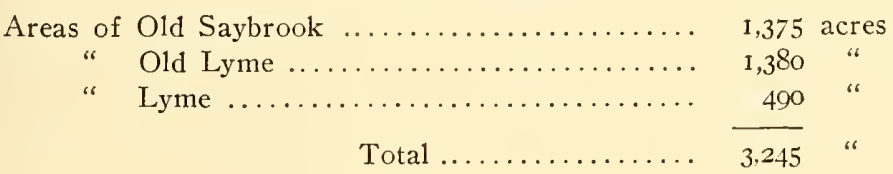

DITCHING REQUIRED :

Io $\times 30$-inch laterals Old Saybrook ............236,500 feet

" " " O1d Lyme ............ 265,000"

" 6

Lyme

10,000

Total

5 I I,500 
$2 \times 3$-foot secondary ditch Old Saybrook ....... 10,700 feet

" " Old Lyme $\ldots \ldots \ldots \ldots \ldots+\frac{200}{10,900}$ "

Larger special ditches Old Saybrook ......... 3,100 “

$\cos \mathrm{T}:$

Cleaning old ditches Old Saybrook ............. $\$ 400.00$

" " " Old Lyme ............... $\quad 250.00$

Cutting lateral ditches Old Saybrook ........... $5,900.00$

" " " Old Lyme .............. 6,850.00

" " " Lyme ................ 250.00

Digging of $2 \times 3$-foot ditches Old Saybrook ........ 550.00

" " " " " Old Lyme ........... 50.00

Special ditches Old Saybrook ................ 400.00

Cost of special work Old Saybrook ............. 550.00

" " " Old Lyme $\ldots \ldots \ldots \ldots \ldots \ldots \ldots . \quad 700.00$

Total cost for salt marshes ........... $\overline{\$ 15,900.00}$

By eliminating certain areas as mentioned in the notes this sum could be reduced to the neighborhood of $\$ 15,000.00$.

The rough estimate of the fresh water areas made under conditions mentioned above is:

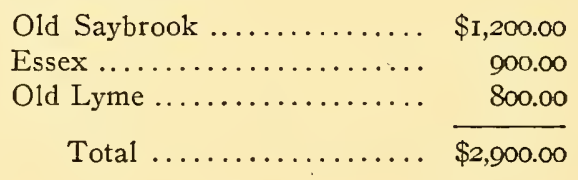

Grand Total .......\$18,800.00

Notes on Township of Old Saybrook.

INTRODUCTION.

In Old Saybrook Township the breeding areas have been divided into two classes, salt marsh and fresh water areas, and each is discussed separately. The salt marshes being the more important are discussed first.

\section{SALT MARSHES.}

The salt marshes may further be divided more or less naturally into six groups as follows:

Chalker Beach and Chapman's Point Marshes (Nos. I-3 on map). 
Oyster River Marshes (Nos. 3-7 on map).

Back River and Plum Bank Creek Marshes (Nos. 8-2I on map).

South Cove and Fenwick Point Marshes (Nos. 22-40 on map).

North Cove and Church House Marshes (Nos. 4I-48 on map).

Marshes north of railroad line (Nos. 48-52 on map).

Of these groups, the first, third and fourth are the most important-not so much because of their proximity to the settled portion of the town as because of their breeding qualities. Marshes north of the railroad are both remote and largely nonbreeding and therefore of comparatively little importance. The Oyster River and North Cove and Church House marshes are moderate breeders and close enough to the settled portions of the town to require consideration but excepting the marshes north of the railroad are less important than the others.

If there is only a limited sum of money available so that only a portion of the area can be treated, the above will serve as a guide to indicate the sections which can best be omitted.

\section{Detailed Description of Individual Salt Marsh Breeding Areas.}

The following points regarding individual breeding areas are taken up:

Location of Area. Each area is numbered and in some cases also named. These numbers and names also occur upon the map and afford a ready means of locating it.

Grade of Breeding. Expressed by letters from A to E, the significance of which has been explained on pages 9 and Io. In the case of grass breeding areas, a figure giving approximate percentage of the surface of the marsh capable of breeding mosquitoes is also given.

Size of Area. Given in acres and tenths of acres.

Vegetation and Value of Salt Hay. Brief description only.

Work Necessary to Eliminate Mosquito Breeding. Gives footage of ditching of various sizes required as well as other work necessary. The requirements for lateral ditch of $\mathrm{IO}^{\prime \prime} \times 24^{\prime \prime}-$ $30^{\prime \prime}$ dimensions are given in terms of the average distance apart these ditches should be placed. The common distances are I5O and 200 feet. They are expressed thus: I/I50, I/200, etc. 
Cost. This is figured in accord with the footage rates given on section 9 , page 8 , of the Introduction.

\section{DESCRIPTIONS.}

\section{Chalker Beach and Chapman's Point Marshes.}

I. Class B, 40 per cent. breeding surface. Area, 23.3 acres (approximate). Hay very poor. The outlet of this marsh is a channel parallel to the beach and drains into area No. 2, but it is blocked by the roadway to Chalker Beach. A culvert should be placed under this road at a cost of perhaps $\$ 100.00$. A I/200 ditch system should be constructed. Footage required, 4,850. Cost, \$121.25. With culvert, \$221.25.

2. Class $\mathrm{B}$, with 25 per cent. breeding surface. Area, 93.3 acres. Hay poor, but cut to some extent. This marsh has a number of sodden covelike areas where breeding is intensive. Most of these have ditches into them but they are badly blocked and should be reopened and a new I/200 system dug. Footage required, I9,400. . Cost, $\$ 485.00$.

3. Class B, with 85 per cent. breeding surface. Area, 4.5 acres, on which the hay is cut. This marsh is a particularly bad breeder because the main drain is largely choked and the outlet is almost entirely blocked by cottages. This main ditch should be opened $(2 \times 3$ feet $)$ and the outlet restored. Perhaps a 2 -foot tile drain 50 feet across the beach would insure this outlet being kept open. Cost, about $\$ 75.00$. Lateral ditches, I/I50 feet, should also be cut. Amount of ditching required, I,250. Cost, \$31.25. Total cost, cleaning, ditching and installing drain, \$106.25.

\section{Oyster River Marsh.}

4. Class B, io per cent. breeding surface. Chiefly at the lower end. Area, 13.6 acres. Hay mostly sedge, but is cut. A few old ditches running into odd corners should be opened and a $\mathrm{I} / 200$ system of lateral ditches cut. Footage required, 6,300. Cost, \$157.50.

5. A Class D area of 6.5 acres. Upper end fresh, but marsh should be treated as a unit. It produces good black grass hay but is rapidly deteriorating owing to obstruction of ditches and will soon be breeding as a Class B area. The culvert under roadway should be enlarged to 3 feet in diameter and a tide-gate installed. Probable cost, \$200.00. A 2 -foot ditch should be dug through the center of this area and a I/I50 system of laterals cut. Footage, main ditch, 800 ; cost, $\$ 40.00$; laterals, I,800; cost, $\$ 45.00$. Total cost, $\$ 285$.00.

6. Class B, 40 per cent. breeding surface, except at upper end near railroad where it is Class C west of creek and Class D east. Area, 45.4 acres. Formerly a good hay meadow but now largely sedge grass with many bare spots. Requires a I/I50 ditching system over whole marsh and the reopening of main ditches into various ends. Footage required, I3,200. Cost, $\$ 330.00$. 
7. Class $\mathrm{E}$, lower end, $\mathrm{C}$, and a $\mathrm{B}$ area as indicated by $\mathrm{X}$. Area, 42.I acres (approximate). Salt marsh changing into fresh. Cat-tails and 3-square grass. Upper end probably a fresh water breeder but rather remote to be of much consequence. Tide gate where road crosses is in poor condition and needs repairing. If this marsh is entirely ditched a I/200 system should be installed. Footage, 8,800. Cost, \$220.00. But 1,500 feet at lower end near railroad might answer all practical purposes and cost would be only $\$ 37.50$.

\section{Back River and Plum Bank Creek Marshes.}

8. Class B, along shores of island Class A. Fifty per cent. breeding surface in Class $B$ portion. Area, 56.4 acres. Hay thin, mostly sedge grass. Requires a I/I50 ditching system. Footage, 16,300. Cost, $\$ 407.50$.

9. Class C. Area, 4.5 acres. Hay good but cannot be cut with machine on account of pools. Requires a I/200 ditching system. Footage, 900. Cost, $\$ 22.50$.

Io. Class B, ro per cent. breeding surface. Area, 53.I acres. Numerous sodden cove-like portions, some cut off by roadway. Hay fair in spots, mostly sedge grass. All old ditches should be reopened and culverts placed under roadway. Cost, $\$ 25.00$ more or less. Cut a I/I50 ditching. system. Footage, I 5,400. Cost, $\$ 385.00$. Total cost, $\$+1$ Io.00.

I I. Class B, Io per cent. breeding surface. Area, I7.8 acres. Hay very thin. An old roadway to island was made by throwing a dike across a branch of the creek. This should be cleared away and a bridge substituted to secure rapid draining of sodden areas up stream. It would be about a week's work for one man to clear away this old dike. Cost, \$10.00$\$ 15.00$. Besides that a $\mathrm{I} / \mathrm{I}_{50}$ system of ditches should be installed. Footage, 5,200. Cost, \$I30.00. Total cost, \$I45.00-\$I 50.00.

(See No. I7 for description of channel draining through this area.)

12. Class D. (Owing to influence of a few local ditches.) Area, 8.4 acres. It should be treated along with rest of marsh and a $I / 150$ system dug using old ditches where possible. Hay fair. Footage required, 2,400. Cost, $\$ 60.00$.

I3. Class B, 20 per cent. breeding surface, upper end covered with cattail. Area, 6.5 acres. No hay to amount to anything. Open main drain, $2 \times 3$ feet, and cut $1 / x_{50}$ laterals. Footage required: main ditch, I,000; laterais, I,900. Cost: main ditch, $\$ 50.00$; laterals, $\$ 47.50$; total, $\$ 97.50$.

4. Class B, 25 per cent. breeding surface. Area, 20.I acres. Hay very scant. Clean present ditches as indicated on map and add a $\mathrm{I} / \mathrm{I} 50$ ditching system. Footage: cleaning, 900; new ditches, 5,800. Cost: cleaning, $\$ 22.50$; new ditches, \$I45.00. Total, \$167.50.

I5. Class E. Cat-tail marsh. Area less than I acre. Open main drainage course, length, 350 feet. Cost, $\$ 8.75$. 
I6. Class $\mathrm{B}$, 50 per cent. breeding surface. Area, I6.2 acres. Open $2 \times 3$-foot channels into various cove-like areas as per map and add I/I50 system of lateral ditches. Footage: 2 -foot channels, 2,000; laterals, 4,700. Cost: main channel, \$100.00; laterals, \$II7.50. Total, \$217.50.

I7. Class B (A along western edge), breeding surface 90 per cent. potential, probably never attains this figure or anything like it, as fish are apparently always present in some of the pools. Area, 71.3 acres. Hay largely valueless. So much water remains upon this area most of the time that it will be necessary to reopen the half obliterated channel east of the island through No. II. This channel should be made at least 4 feet deep and 3 feet wide. The present channel should be cleaned and straightened and extended to the upper end of the marsh so as to connect with the various fresh water breeding areas draining into it. $2 \times 3$-foot ditches should also be dug into the various corners as shown on the map and a I/200 system installed. Footage: new outlet, I,300; extension of main ditch, 3,500; laterals, 12,700. Cost: new outlet, \$130.00; extension main ditch, \$175.00; laterals, \$317.50. Total, \$622.50.

I8. Class $\mathrm{B}$ and $\mathrm{C}$, 40 per cent. breeding surface. Area, 6.5 acres. One-third sedge grass hay. Requires I/I50 ditching system. Footage, I,900. Cost, $\$ 47.50$.

I9. Class B and C, 35 per cent. breeding surface. Area, 36.9 acres. No hay. Requires I/I50 ditching system. Footage, I0,700. Cost, \$267.50.

20. Class $B$ and $C$, 50 per cent. breeding surface. Area, 33.0 acres. No hay. Ditching system, I/200. Footage, 6,900. Cost, \$172.50.

2I. Class B, 85 per cent. breeding surface. Area, 18.8 acres. No hay. Open new ditch $2 \times 3$ feet into corner as indicated by map and ditch I/200. Footage: 2-foot ditch, I,200; laterals, 4,000. Cost: 2-foot ditch, $\$ 60.00$; laterals, \$100.00. Total, \$160.00.

\section{South Cove and Fenwick Point Marshes.}

22. Class B, 20 per cent. breeding surface. Area, I3 acres. Hay fair. Clean upper ends of existing ditches and add a I/I50 system. Footage, 3,800. Cost, $\$ 95.00$.

23. Class A. Area, 6.5 acres. Hay of little or no value. Make extra outlet $(2 \times 3$ feet) through neck of highland, which is only I foot above marsh level, as shown on map, and cut I/Ioo laterals. Footage: new outlet, 670 ; laterals, 2,500. Cost: new outlet, $\$ 35.00$; laterals, $\$ 62.50$. Total, $\$ 97.50$.

24. Class B, A along inner edge. Forty per cent. breeding surface. Area, 3.2 acres. Hay fair. New ditches, I/I50. Footage required, 900. Cost, \$22.50. 
MAP OF

MOSOUITO BREEDING AREAS AT MOUTH OF THE CONNECTICUT RIVER.

\section{ByPL Buttrick. SpecialAgent}

Prepored Under the Direction of the

CONWECTIUUT AGRICULTURAL EXPLRIMENT STATION.

New Haven. Connectiout

August 1915 .

\section{LEGEND}

Fresh water monshes..........

verious colors Tepresent differences

in breeding condirrons.
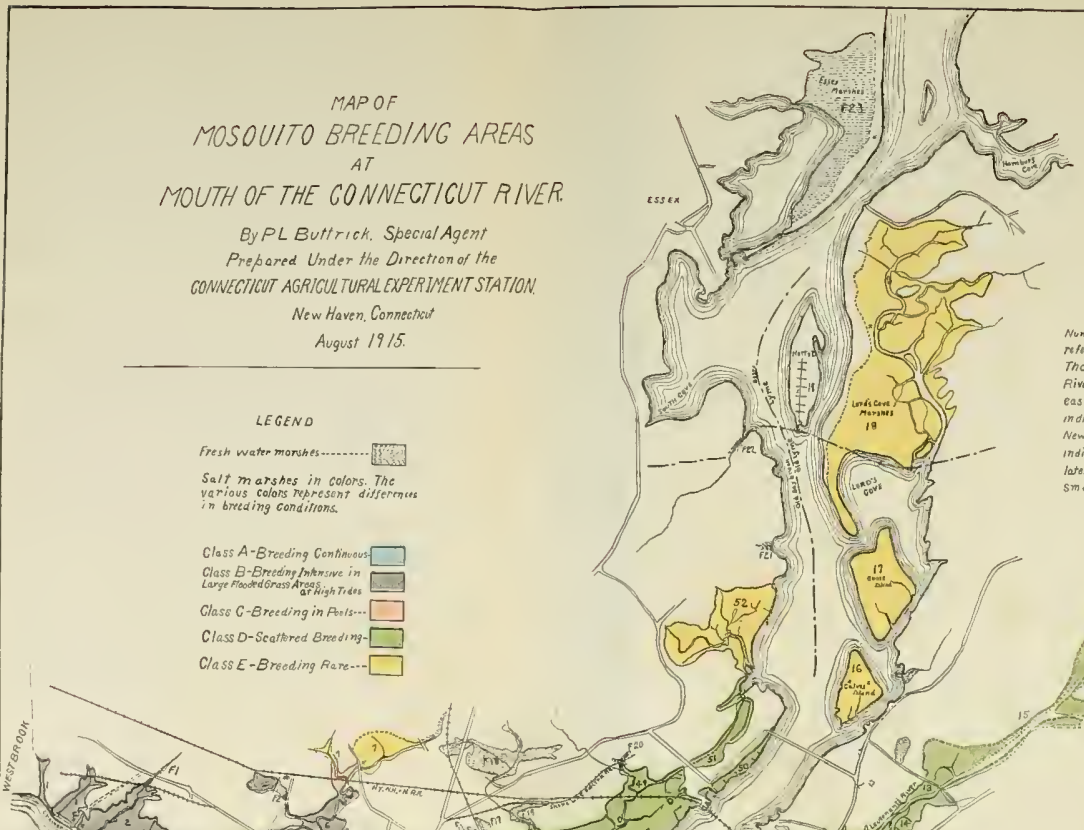

Numbers on dillerent Marsh Arevs refer to Describtrons in Aeport. Those west of the Connecticur iver refer fo Saybrosk Those eft of to Lyme. Crosses $[x]$ intensive bresding. main ditches required are atera ditches not shown owing to mall seale of map
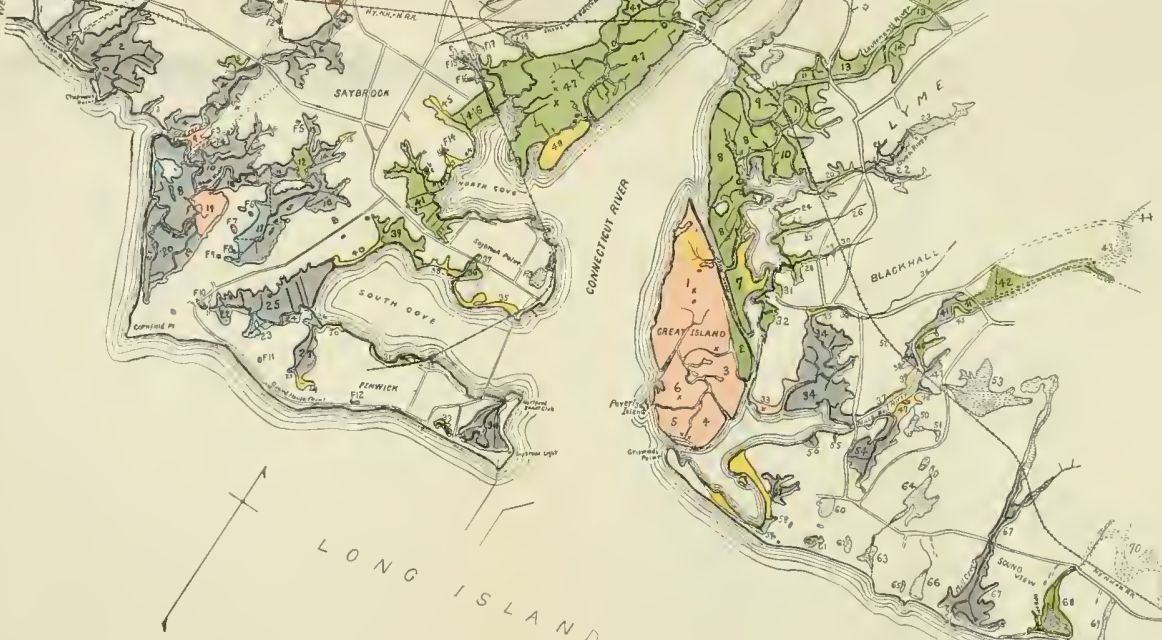

25. Class B, 15 per cent. breeding. Area, 58.3 acres. Good hay meadow but beginning to deteriorate. Larger ditches in fair shape but smaller ones badly choked and need cleaning. New ditches required I/200 system. Footage: old ditches to be cleaned, 2,800; new ditches, 12,000. Cost: cleaning old ditches, \$70.00; digging new ones, \$300.00. Total, \$370.00.

26. Class A. Area, 3.2 acres; no hay. Open main channel $2 \times 3$ feet, length 350 feet, and ditch I/I00. Footage, I,300. Cost: main ditch, \$I8.00; laterals, $\$ 32.50$. Total, $\$ 50.50$.

27. Class B, 20 per cent. breeding surface. Area, I4.9 acres. Hay light. Clean upper portion of main channel and ditch I/I50. Footage, 4,300. Cost, \$107.50.

28. Class A. Area less than I acre. No hay. Requires I main and I cross ditch. Footage, 500. Cost, \$12.50.

29. Class E. Area, 3.2 acres. Black grass hay. Clean main ditch, I,000 feet. Cost, $\$ 25.00$.

30. Class E. Area 3.2 acres. No hay. Ditch I/200, footage, 650. Cost, $\$ 16.25$.

3r. Class D. Area, 3.9 acres. A little hay. Ditch I/200, spaced closer toward eastern end. Footage, 800. Cost, \$20.00.

32. Class C. Area less than I acre. Hay good. Has ditching system which is badly clogged. If opened would be sufficient. Cost, \$10.00.

33. Smaller lagoon at Fenwick Point. Shores of this lagoon are a Class D salt marsh. Area, I.9. Edges here should be cleaned up and the material thrown back upon the marsh which should then be ditched I/Ioo. Footage, 800 . If it is decided to excavate this marsh sufficiently to add to the lagoon and use excavated material to fill in other portions so that marsh is entirely abolished a special estimate will have to be prepared.

The costs of ditching as laid out will be about $\$ 20.00$.

34. Fenwick Point marsh and larger lagoon. This is a Class B marsh with 50 per cent. breeding. Area, 25.3 acres. Hay of little value. Drain, I/r5o. Footage, 7,300. Cost, $\$ 182.50$. Probably it will be necessary to lower outlet by removing rocks below bridge (a small job) and to install tide gates at that point. Measurements: Distance across bridge, I3 feet. Height from stream bed to bridge head, 6 feet. Depth of water at high tide, $4 \frac{1}{2}$ feet. Bottom sand and rock. Runway rock-faced, tight enough to support gate. The cost of such a gate would probably not exceed $\$ 50.00$, including deepening of channel below. A desirable way in which to treat this whole marsh would be to erect a sod dike around the lagoon and along the stream draining it, put in a tide gate as indicated and fill in the marsh with material from the channel the next time it is dredged. Total cost of ditching and tide gate, $\$ 232.50$. 
35. Class $\mathrm{E}$, but a single bad $\mathrm{B}$ area as indicated by $\mathrm{X}$. Area, 8.4 acres. Hay in pockets is good but along shore is valueless. Ditches $I / 300$. Footage, I,200. Cost, $\$ 30.00$.

36. Class B west of creek, D east. Area, I3 acres. Salt grass hay. Clean old ditches and add equal amount of new to connect with 37 . Old ditches, I,500; new ditches, I,500. Cost : old ditches, $\$ 37.50$; new ditches, $\$ 37.50$. Total, $\$ 75.00$.

37. Class D, possibly B. Area, I acre. Hay fair. Clean ditches ( 400 feet) and open culvert. May be necessary to enlarge this culvert. Cost for cleaning ditches, \$10.00.

38. Class E. A-few small B places. Area, 3.2 acres. Hay black grass. Ditch I/250 but spaced according to necessity. Footage, 800. Cost, $\$ 20.00$.

39. Class D. Area, I7.5. Good hay. Ditch I/200 where needed. Footage, 3,600. Cost, $\$ 90.00$.

40. Class E. Area, 7.I acres. Hay doubtful. No treatment required beyond keeping ditches open.

\section{North Cove and Church House Marshes.}

4I. Class D. Area, 5I.2 acres. Salt and black grass hay. Upper end of many branches covered with cat-tails. This area has a good ditching system, but ditches should be thoroughly cleaned and opened, or in a few years marsh will be in bad shape. A marginal ditch should be dug around whole meadow to look after casual breeding along inner end and ditches to main creek should be dug into ends at $a, b, c$ and $d$. Footage, old ditches to be cleaned, 7,000 more or less. New ditches, ro,000 more or less. Cost: cleaning old ditches, \$I00.00; digging new ones, $\$ 250.00$. Total, $\$ 350.00$.

42. Class D. Area, 3.2 acres. Hay good. Requires ditching I/I50 and a marginal ditch. Footage, I,000. Cost, \$25.00.

43. Class E. Area, 2.6 acres. To clean existing ditches is enough. Cost, \$10.00-\$15.00.

44. Class E. Area less than an acre. No treatment required.

45. Class E. Largely cat-tails, upper end potential fresh water and malarial breeder. Area, 3.2 acres. Open main channel $2 \times 3$ feet through 46 to cove. Footage, I,200. Cost, $\$ 60.00$.

46. Class D. Area, I2.9 acres. Good hay. Marsh fairly well ditched, but new ones should be spaced between existing ones where distance exceeds 400 feet between them. Footage, 2,000, more or less. Cost, $\$ 50.00$.

47. Church House Lot. Class $\mathrm{D}$, a few $\mathrm{B}$ or $\mathrm{C}$ areas as indicated by $\mathrm{X}$. Otherwise breeding is casual. Area, 309 acres. Inner edge largely cattails and most of larger ditches are bordered by them or equivalent vegetation. Outer portions mostly black grass; other parts excellent salt grass. 
By cleaning old ditches and cutting new ones where distance between present ones exceeds 400 feet, area could be made mosquito proof. Footage required, 2,500. Cost, $\$ 62.50$.

48. Island part of Church House Lot, Class E. Area, I9.4 acres. Mostly black grass hay. A I/300 ditching system would drain a few potential breeding pools and improve the hay. Footage, 2,500. Cost, $\$ 62.50$.

\section{Marshes North of Railroad Linc.}

49. Class D. Area, 29.8 acres. Mostly good black grass hay but there are a few bad breeding corners as indicated by Xs. The ditches in some of them are badly clogged and are breeding both Culex and Anopheles. These should be cleaned carefully and a new I/200 system opened. Footage: old ditches, 2,000; new, 6,200. Cost: old ditches, $\$ 20.00$, new, \$155.00. Total, \$175.00.

50. Class D. Area, I2.9 acres. Distinctly a salt marsh but now breeding fresh water mosquitoes in clogged ditches. Hay, red salt grass. Open old ditches and ditch I/200. Footage: old ditches, I,600; new ditches, 2,600. Cost: old ditches, $\$ 20.00$; new ditches, $\$ 65.00$. Total cost, $\$ 85.00$.

5I. Class D. Area, 32.4 acres. Lower end (north) brackish, upper end (south) practically fresh, breeds Culex and Anopheles and might easily become a plague spot although not now bad. Is classed as a salt marsh because of its vegetation. A main ditch $4 \times 4$ feet square and an outlet cut under Ferry Road to 49 would probably be sufficient. Footage of ditch required, I,800. Cost, $\$ 300.00$, more or less. Cost of culvert under road, \$150.00, more or less. Total, $\$ 450.00$, more or less.

52. Class E. Area, IIo.8 acres. Largely cat-tail (outer portion) and 3-square grass (inner) brackish, breeds both salt and fresh water mosquitoes. To render entirely safe a I/200 ditching system required but as compared with other areas scarcely worth doing. Footage, 23,000. Cost, $\$ 575.00$.

\section{Fresh Water Breeding Areas.}

Although no special attempt was made to study the fresh water breeding places of the town, enough were seen to warrant a brief description of them, together with a few general comments.

Malarial Breeding Places. Practically all fresh water breeding places examined are capable of breeding the Anopheles or malarial mosquito, and wherever sufficient search was made they were found breeding. That Saybrook (and the same is true of Lyme) does not suffer extensively from malaria is apparently due to the absence of the disease itself rather than to the absence of its hosts. Certainly the stage is set for an epidemic and should a sufficient number of cases become established the disease would probably speedily become widespread. 
Advisability of Controlling Fresh Water Breeding Places. As far as obtaining freedom from the mosquito nuisance is concerned little or nothing would be accomplished save here and there locally to do away with the fresh water breeding areas, although the menace of malaria would be eliminated. On the other hand, to abolish the salt marsh breeding areas and leave the fresh water ones untouched would practically abate the nuisance except in the immediate neighborhood of the fresh water areas but would do nothing to eliminate the danger of malaria.

In case funds are not forthcoming to do both, it is our opinion that some of the salt marshes up the river could be safely neglected and the money necessary to ditch them be spent instead on some of the large and more important fresh water areas near the village.

Kinds of Fresh Water Breeding Places. There are several kinds of fresh water breeding places in Saybrook: (I) The inland ends of many of the salt marshes are often fresh or at least only faintly brackish. These are often cat-tail areas. They are generally not very serious breeders and can best be treated along with the salt marshes of which they are really a part.

Open Fresh Marshes. Many of these are covered with cattails, but are frequently bad breeding areas and produce many malarial mosquitoes. They must be ditched or otherwise treated.

Wooded Marshes. These are apt to breed mosquitoes only early in the season and are seldom of much importance-at least so long as the other areas are untreated.

Sink Holes. Sometimes these areas are swampy and sometimes are open pools or puddles. The latter are usually less troublesome. The best treatment of sink holes is to fill them. By the use of a team and a drag scraper such an operation is not expensive, and at a trifling expense an area capable of cultivation takes the place of a breeding hole. When filling is not practicable an outlet should be provided.

Edges of Sluggish Streams. These are sometimes bad breeding places for malarial mosquitoes but there seem to be few places of this kind in Saybrook.

Following is a brief description of some of the important fresh water breeding places west of the Connecticut River. The estimates of cost are very rough but should come within 30 per cent. 
The total estimated cost of treating the fresh water breeding places is $\$ \mathrm{I}, \mathrm{I} 75.00$, not including the Essex marsh.

\section{Description of Individual Fresh Water Breeding Areas.}

F I. Open marsh, semi-permanent breeder. Open main drain into 2. Footage, I,600. Cost, $\$ 50.00$, more or less.

F 2. Lily pond and open swamp, permanent breeder. Lower the outlet to pond so as to drain swamp. (Not an expensive job. Cost, perhaps, \$25.00.)

F 3. Fresh water pond hole, constant breeder on small scale. Open channel to salt marsh 50 feet away. Cost, perhaps, $\$ 35.00$.

F 4. Pond hole once connected with marsh at Io. Reopen ditch.

F 5. Two wooded sink holes each about Ioo feet in diameter. Permanent or semi-permanent breeders. Fill to depth of 4 feet, moving earth from surrounding banks. Requires movement of 2,000 cubic yards of earth. The cost of moving with drag scraper would be about Io cents per yard or about $\$ 200.00$.

F 6. Two wooded sink holes. Permanent or semi-permanent breeders. Their treatment would be rather expensive as it would be necessary either to cut off the timber and scrape earth into them, or else to cart it from a distance. A 25-foot bank lies between them and the salt marsh, calling for considerable excavating which would make it expensive to open an outlet. It would probably cost $\$ 250.00$.

F 7. Wooded sink hole, permanent or semi-permanent breeder. Open drain to salt marsh at I7, I00 feet away. Cost, $\$ 25.00$, more or less.

F 8. Pond hole semi-permanent breeder. Dig drain into salt marsh at $\mathrm{I} 7$, some 60 feet distant. Cost, \$I5.00, more or less.

F 9. Pond hole, permanent or semi-permanent breeder. Place culvert under roadway to salt marsh at $I 7$, some 25 feet distant. Cost, with 24-inch tile pipe, about $\$ 40.00$.

F Io. Swampy pool on both sides of Cornfield Point road. Place culvert under old roadway to drain portion east of highway and fill the west portion. Cost of both operations, perhaps, $\$ 60.00$.

F II. Pond hole $100 \times 50$ feet and 3 feet deep. Breeds along edges and might be filled but unimportant till much other work is done.

F I2. Low lying grass area. Breeds only during very wet seasons. I50 feet of ditch, I2 X I8 inches through center parallel to road, and a culvert under road to beach would probably keep this area dry. Cost, probably $\$ 15.00$ to $\$ 25.00$. 
F r3. Fresh water lagoon and cat-tail swamp at Saybrook Point. Area of swamp, 6.5 acres. Breeds whenever water stands in the cat-tails. It would be futile to ditch this area as it stands, since the water stands at the same level in the swamp as in the lagoon, but if an opening were made into the river so that the tide would rise and fall in the lagoon, then by ditching the marsh breeding could be checked. Footage of ditch required for marsh would be 1,300 . Cost, at $2^{1} / 2$ cents per foot, \$19.50. The cost of placing culvert under railroad might be as high as $\$ 100.00$. A 4-foot tile drain would not be too big.

F 14. Small fresh water and cat-tail swamp. Requires 300 feet of main ditch and roo feet cross ditch opening into a culvert draining into 43. Cost, $\$ 40.00$, or less.

F 15. Fresh water cat-tail swamp and shallow lagoon draining into 46, through ditch parallel with railroad. This is a large and intensive malarial breeding place and should have attention. The drainage ditch is rather badly choked and should be thoroughly cleaned. Two-foot drains should then be dug to each neck of marsh. Total footage, 2,500. Cost, \$125.00. Cleaning main ditch, $\$ 25.00$.

F i6. Open fresh marsh. Drainage badly choked. Open up drain to outlet from F 15. Length, 500 feet. Cost, $\$$ I5.00, more or less.

F I7. Fresh marsh, upper end wooded, lower end covered with cat-tail. Open up channel into creek in 47 .

F I8. Large marsh back of railroad station at Saybrook Junction with growth of wood and cat-tail. In wet seasons it may breed mosquitoes. enough to be dangerous and annoying; in an ordinary season it may give no trouble at all. The only remedy is to open up the main channels and add laterals if it becomes necessary. The main channels are about 6,000 feet long, and it might cost $\$ 150.00$ to clean and open them.

F I9. Small wooded marsh of little consequence.

F 20. Small pond edged with cat-tails and swamp. Clean up the edges.

F 21 and 22. Cat-tail swamps. Too small and remote to be of consequence.

F 23. Essex Marsh area, I55 acres. Vegetation, cat-tails and sedges of various kinds. At time of visit water stood over whole marsh and it was in condition to breed fresh water mosquitoes abundantly. However, in a dry season it probably would be much less dangerous. This marsh even at its worst is probably of little importance to Old Saybrook and Old Lyme. There would be no difficulty about draining it. A $1 / 200$ system should be sufficient. Footage, 32,000. Cost at $2 \frac{1}{2}$ cents per foot. $\$ 900.00$. 
Summary of Costs for Saybrook.

Area I,373.5 acres

Cost of cleaning old ditches ................ \$ 405.00

Footage of lateral ditches, 236,500; cost ......... 5,912.00

Footage, 2' $2^{\prime} 3^{\prime}$, secondary ditches, I0,720; cost ....... 538.00

Footage, larger special ditches, 3,$100 ;$ cost ......... 430.00

Tide gates, culverts, etc.; cost ................ $\mathbf{5 4 0 . 0 0}$

Total for salt marshes $\ldots \ldots \ldots \ldots \ldots \ldots \ldots \ldots \overline{\$ 7,825.00}$

Total for fresh marshes ............. I,I75.00

Total for town of Old Saybrook .......... \$9,000.00

Essex Marshes ................. 900.00

Total west of River ............. $\overline{\$ 9,900.00}$

Average cost per acre for work on salt marshes is estimated at $\$ 5.70$.

\section{Notes on Townships of Lyme and Old Lyme.}

The salt marshes of Lyme may be divided not altogether arbitrarily into the following groups:

Great Island, Nos. I-6 inclusive.

Back River, Nos. 7-10 inclusive.

Lieutenant River, Nos. II-I 5 inclusive.

Up-river marshes, Nos. I6-I9 inclusive.

Duck River and Black Hall marsh, Nos. 20-32 inclusive.

Black Hall River marshes, Nos. 33-56 inclusive.

Shore marshes, Nos. 57-75 inclusive.

Of these groups the Great Island, Duck River and Black Hall, and Black Hall River marshes are the most important. The Lieutenant River and Back River marshes are of little importance despite their proximity to the settled portions of the town, owing to their character, while the up-river marshes are both remote and sparse-breeding. The shore marshes are some of them bad breeders but constitute a separate problem for the people of Sound View, South Lyme and the various shore resorts of the section, and east of the Mill Creek marsh the shore marshes might be safely disregarded as far as their effect on the village of Old Lyme is concerned.

The fresh water breeding areas of Lyme, excepting along the south shore, are chiefly at the upper ends of the salt marshes and 
will largely be taken care of along with them. Along the south shore some of the old salt marshes which have become fresh require special treatment as has been mentioned under the detailed descriptions.

Although the notes for fresh and salt breeding areas are not separated in the summary, they are so far as possible tabulated under different headings.

Much of the introductory matter given for Saybrook (see page I2) also applies to Lyme.

\section{Detailed Description of Individual Breeding Areas in Lyme and Old Lyme Townships.}

\section{Great Island Marsh.}

I. Class $\mathrm{C}$ except at $\mathrm{X}$ s where moderate-sized B areas exist and near the north end where there is an E cat-tail area. Except on this area hay is good red top. Area, I7I.I acres. The creek branches much more than is shown on map, extending nearly to the lower islands, but is rather clogged with vegetation. It should be cleaned out and a I/200 system installed with reference to it and to the shore. Footage, 35,590. Cost, $\$ 889.75$. The cost of cleaning out the creek can only be guessed at, but I should think it might cost $\$ 200.00$, more or less. Total cost, $\$ 1,089.75$.

2. Class D, a few small B spots. Area, I5.6 acres. Excellent black grass hay. Will not require more than $1 / 300$ ditching spaced so as to drain individual breeding places. Footage, 2,750. Cost, $\$ 68.75$.

3. Class C. Good salt and black grass hay. Area, 46 acres. Ditch I/200. Footage, 9,570. Cost, $\$ 239.75$.

4. Class C. Hay fair along lower end, excellent at upper end. Area, 33 acres. Requires ditching $\mathrm{I} / 200$ average but rather closer at the lower end. Footage, 6,860. Cost, \$171.50.

5. Class $C$, except at $X$ which is B. Area, I6.8 acres. Poor quality salt grass hay. Requires, I/I50 ditching system. Footage, 4,870. Cost, \$12I.75.

6. Class $\mathrm{C}$, except at $\mathrm{X}$ which is $\mathrm{B}$, an acre or so of solid 95 per cent. breeding. Area, 36.9 acres. Upper end good black grass hay but of course many holes and small grass breeding depressions exist. Requires ditching I/200. Footage, 7,670. Cost, \$191.75.

Note. The total area of Great Island is 319.4 acres and the estimated cost of ditching and other improvements is $\$ \mathrm{I}, 882.75$. 


\section{Back River Marshes.}

7. Nameless island, Class D. On east side of the island chiefly wild rice grows, on the west side black grass. Area, 29.8 acres. Western side requires ditching $\mathrm{I} / 200$. Footage required, 3,100. Cost, $\$ 77.50$.

8. Class D, but scattering non-breeding areas. Chiefly cat-tail covered, rest hay grasses. Area, I35.4 acres. Requires $1 / 300$ ditching. Footage, 19,630. Cost, $\$ 490.75$.

9. Class D. Black and salt grass hay. Area, 42.I acres. Clean old ditches and add I/200 new ones. Footage: old ditches, 700, more or less; new ditches, 8,760. Cost: cleaning old ditches, \$17.50; digging new ones, \$209.00. Total, \$226.50.

Io. Class D, except the portion above railroad embankment which is $B$. Area, 48.8 acres. Black grass and cat-tails. Main channel in portion above railroad should be opened, length 200 feet, and made $2 \times 3$ feet and 200 feet of laterals dug. If it proves necessary a tide gate should be hung on the culvert under the railroad. Cost, $\$ 25.00$, more or less. The main marsh should be ditched $\mathrm{I} / 200$ but by using present ditches the total amount can be reduced probably 30 per cent. Footage required, 7,100. Footage, $2 \times 3$-foot ditch, 200. Cost, at 5 cents per foot, \$ro.0o. Cost, lateral ditches, $\$ 177.50$. Total cost, $\$ 185.50$.

\section{Lieutenant River Marsh.}

II. Class D, possibly rarely breeds as a B area. Area, 9.7 acres. Good salt and black grass hay. Requires ditching I/I25. Footage, 3,200. Cost, $\$ 80.00$.

12. Class D. Area, 32.4 acres. About 40 per cent. of this area is covered with cat-tails which follow the creeks and ditches and cover most of the ends and pockets, thus preventing them from being bad breeders. Outside of this the vegetation is mostly of hay grasses. Channels should be opened into the various ends and ditches dug in spaces where distance between existing ditches exceeds 400 feet. Estimated footage of $2 \times 3$ ditch 200 , of laterals 3,500 , more or less. Cost, $2 \times 3$-foot ditch, $\$ 10.00$; laterals, $\$ 87.50$. Total, $\$ 97.50$.

I3. Class D. Area, I6.2 acres. Hay good. Requires I/200 ditching. Footage, 3,37o. Cost, $\$ 84.25$.

I4. Class D. Area, 32.4 acres. Partly cat-tails; rest good hay. Requires ditches into dead ends and I/200 system. Footage, 6,740. Cost, $\$ 168.50$.

I5. Class D, or possibly E. Upper Lieutenant River Marsh; lower end salt; upper brackish or perhaps entirely fresh. Vegetation mostly cattails and sedges of various kinds, the two being about equally divided. Approximate acreage, I62 acres. The lower end of this marsh is a typical Class D area. Above, where it is brackish or fresh it may breed fresh 
water species more or less, but owing to its remoteness could possibly be neglected. To properly ditch this marsh would require a $\mathrm{I} / 200$ system. Footage, 33,700. Cost, $\$ 842.50$. Probably one-third of this sum spent on the lower end would be sufficient.

\section{Up-River Marshes.}

r6. Calves Island. Class E, with few B spots as indicated. Area, 44.I acres. A typical salt marsh; vegetation mostly black grass. This area is probably seldom flooded. A I/300 ditching system, spacing ditches so as to drain individual pools would be sufficient. Footage, 6,390. Cost, \$159.75.

17. Goose Island. Class E. Area, 88.8 acres. Mostly cat-tails except along eastern shore where it is an old black grass marsh, but is being rapidly overrun by cat-tails. This outer area might breed more or less but a system of $\mathrm{I} / 200$ ditches extending $\mathrm{I} 50$ feet back from shore would be sufficient to drain it. Footage, 3,000. Cost, $\$ 75.00$.

18. Lord's Cove Marsh. Class E. Area, 492.5 acres. Lower end black grass and cat-tails; upper 3-square grass and cat-tails. The latter together with similar forms of vegetation cover more than 50 per cent. of the marsh and are increasing. They follow the hay ditches and small creeks and are constantly encroaching still further on the general surface of the marsh. Wherever possible hay is still collected and the yield is high. The general character of this area is a low, occasionally flooded meadow, yet even at its north end it is distinctly brackish in character. It is flooded only by heavy rains and freshets. Occasional depressions breed salt marsh mosquitoes in more or less abundance. The highest point of salt marsh breeding actually found was opposite the north end of Nott's Island, as shown by cross on map. In a dry season it would probably breed very few mosquitoes. The only treatment that this marsh requires is to clean some of the smaller ditches and to dig new ones here and there to drain individual breeding areas. Footage, 10,000. Cost, \$250.00. Very rough estimate.

19. Nott's Island. A reclaimed marsh used for hay farming. A few depressions near middle of lower half of the island are breeding salt marsh mosquitoes but in a dry season would probably not do so. A thorough cleaning of existing ditches and a new median ditch would not only render this area non-breeding but would improve its hay yield. Footage: old ditches needing cleaning 4,000; (rough approximation) new ditches, I,000. Cost: cleaning old ditches, $\$ 40.00$; digging new ones, $\$ 50.00$. Total. $\$ 90.00$.

\section{Duck River and Black Hall Marshes.}

20. Lower Duck River Marsh. Class D. Area, 27.2 acres. Sedge grass hay, but is used. Clean existing. ditches, particularly those running into the various ends, and ditch I/200. Footage, 5,660. Cost, \$14I.50.

2r. Upper Duck River, Nos. 2I, 22 and 23. Class B. Ten per cent. breeding surface. Area, I2.3 acres. Upper portion and edges brackish and 
covered with cat-tail. Hay poor. Open creek for 200 feet toward upper end and clean culvert under roadway. Ditch I/Ioo. Footage, 5,120. A tide gate at the highway bridge may prove necessary here. A small fresh water lily pond drains immediately into this area. It is a potential malarial breeder on a considerable scale. The edges should be cleaned and the swamp at its upper end dug out. Cost: lily pond, \$100.00; main creek and culvert work, $\$ 35.00$; lateral ditches, \$128.00. Total, \$265.00. Tide gate, if necessary, $\$ 50.00$.

22. Class B, ro per cent. breeding surface. Area, 7.8 acres. Upper end cat-tail and wooded swamp. Straighten main creek and ditch I/Ioo. Footage, 3,240. Total cost, $\$ 81.00$.

23. Fresh marsh. Three-square grass and some cat-tails. Area, I6.2 acres. Probably always contains a few breeding places but particularly bad at this time owing to rains and unsatisfactory condition of salt marsh below. Clean main creek at lower end. This means digging a $2 \times 3$-foot channel I,000 feet long. Cut I/200 laterals. Footage, 3,370. Cost, at 21/2 cents per foot, $\$ 84.25$. Main creek, at 5 cents per foot, $\$ 50.00$. Total, $\$ 134.25$.

24. Class E. Area, 3.2 acres. Excellent black grass hay but ditch is almost blocked and if not cleaned area will deteriorate rapidly. Footage required, 250. Cost, \$10.00.

25. Down-stream portion, Class D; up-stream, B. Area, 9.I acres. Hay is cut. Ditch I/I50. Footage, 2,640. Cost, $\$ 66.00$.

26. VVell ditched fresh marsh now largely reclaimed; satisfactory so long as ditches are kept open.

27. Pond hole 200 feet long, 50 feet wide. Intensive breeder of both salt and fresh water species of mosquitoes. Open outlet to salt marsh at 25 to connect with ditching system there. Length required, roo feet. Height of land between, 2 feet. Cost of $2^{\prime} \times 3^{\prime}$ ditch, approximately, \$15.00.

28. Class D. Area, 9.I acres. Hay good. Ditch I/I50. Footage, 2,640. Cost, $\$ 66.00$.

29. Freşh cat-tail marsh. Area, I acre. Potential malarial mosquito breeder of considerable size. Culvert under roadway at lower end too small. Cost of enlarging, perhaps $\$ 100.00$. Main channel needs cleaning. 300 feet; cost, \$15.00. Laterals, I/I50. Footage, 290. Cost, \$7.25. Total cost, \$122.25.

3o. Upper end of 29 above railroad. In wet weather fresh water and malarial mosquito breeder. Requires main ditch and lateral ditch parallel to railroad embankment, with possible enlargement of culvert under railroad. Footage, 250 feet more or less. Cost of ditch work, \$Io.00-\$15.00.

3I. Class D. Area, 3.2 acres. Clean main ditch (length $200 \mathrm{feet}$ ) and ditch I/I50. Footage, 930. Cost: cleaning creek, \$10.00; lateral ditches, $\$ 23.25$. Total, $\$ 33.20$. 
32. Class D. Area, 6.5 acres. Hay good. Ditch $1 / 150$. Footage, 1,880 . Cost, $\$ 47.00$.

Black Hall River Marshes.

33. Class $\mathrm{C}$, with $\mathrm{B}$ area as indicated. Area, I4.3 acres. Yields good hay but could not be machine cut. Ditch, I/I50. Footage, 4,I50. Cost, $\$ 103.75$.

34. Class B, with 50 per cent. breeding surface. Area, 89.4 acres. This is one of the worst breeding areas encountered in the whole survey; certainly the worst in Lyme, not so much because of the percentage of breeding surface as because it seems to breed regularly with every tide. In rainy seasons such as the present it probably breeds as a Class A area. Hay almost worthless. Many of the dead ends on the eastern side require I/Ioo laterals as well as the cleaning of the central ditches into them. Some parts of the area will require only $1 / 200$ ditching but the average will be I/I50. Footage, 25,930. Cost, $\$ 648.25$.

35. Class E. Area, 6.5 acres. Excellent hay. Well ditched and largely non-breeding but ditches should be cleaned.

36. Fresh marsh fed by sluggish stream. Area, 2.5 acres. Both marsh and stream are potential malarial breeders on a considerable scale. The ditching of the salt marsh at 34 and opening of main channel through swamp portion would go a long way toward quickening the current in the stream. The swamp should be ditched I/I5o. Footage: main ditch, 350; laterals, 720 . Cost: main ditch, at 5 cents, $\$ 17.50$; laterals, at $2 \frac{1}{2}$ cents, per foot, \$18.00. Total, \$37.50.

37. Class D. Area, 5.8 acres. Hay fair. Ditch I/r50. Footage, I,680. Cost, $\$ 42.00$.

38. Class A. Area, I.3 acres. No hay. Open drainage ditch along railroad to Black Hall River at 39 . Footage, 250, more or less. Cost, $\$ 25.00$. Laterals, 200 feet. Cost, $\$ 5.00$. Total cost, $\$ 30.00$.

39. Class C. Area, 6.5 acres. Hay crop fair, but the land is much cut up by pools. Ditch I/I50. Footage, I,880. Cost, $\$ 47.00$.

40. Class B, 25 per cent. breeding surface. Area, 2.6 acres. Hay fair. Ditch I/I50. Footage, 750. Cost, \$18.75.

4r. Down-stream, Class B, 25 per cent. breeding; up-stream, D. Area, II.o acres. Red top and black grass hay. Ditch, I/I80 including main ditch into pocket which runs back to highway. Footage, 2,520. Cost, $\$ 63.00$.

42. Class D. Area, 32.4 acres (approximate). The upper portion of this marsh is only slightly brackish and probably breeds fresh water as well as salt water mosquitoes. Owing to its remoteness the upper portion of this marsh could be neglected if funds for entire eradication measures 
were not forthcoming. Ditch, I/200. Footage (approximate), 6,740. Cost (roughly), \$168.50.

43. Open alder swamp and peat bog. Probably a bad malarial breeder but too remote to greatly affect settled portions of town. Open up course of main stream.

44. Red maple swamp. Probably a semi-permanent breeder. Too remote to be of especial consequence. Clean main channel into 42 and 43 .

45. Class E. Area, I.9 acres. Good non-breeding black grass marsh. No treatment needed at present.

46. Class D. Area, 9.I acres. Fair hay. Ditch $\mathrm{I} / 200$ spacing irregularly as required. Footage, I,89o. Cost, $\$ 47.25$.

47. Class B, 50 per cent. breeding surface. Area, I4.9 acres. Hay fair. Ditch I/I00. Footage, 6,200. Cost, \$155.00.

48. Class B, 25 per cent. breeding surface. Area, I.9. acres. Open main ditch and ditch I/IOo. Footage, 790. Cost, \$19.75.

49. Class C. Outer portion Class E. Area, 6.5 acres. Hay good. Ditch I/I5o. Footage, I,880. Cost, $\$ 47.00$.

50. Brush swamp, a casual fresh water and malarial breeder. Open outlet to salt marsh at 49. Partial overflow outlet already exists. Should be lowered at least 2 feet. Cost, \$15.00, more or less.

5I. Pond hole. Potential malarial breeder on a large scale. A ditch about I50 feet long carries overflow into 50. If this ditch were lowered 8 feet it would probably entirely drain this area. Cost, $\$ 50.00$, more or less.

52. Pond hole. Willows along border. Potential and malarial breeder on considerable scale. Fill to depth of 3 feet and repair culvert under railroad to carry off flood water. Requires 3,000 cubic yards, more or less, of earth. Cost of moving earth, $\$ 300.00$, more or less.

53. Wooded marsh. Potential wet weather breeder but rather remote to be of much consequence. It might be advisable to spend $\$ 25.00$, more or less, to open up outlet in 48 .

54. Class B, Io per cent. breeding surface (average), but varies from $o$ to I0o. Upper end cat-tail covered and Class $\mathrm{E}$ in character. Area, 29.2 acres. Ditch I/200 average, but would require special spacing in some cases. Footage, 6,100. Cost, \$152.50.

55. Class B, 90 per cent. breeding surface. Area, I acre. No hay grasses. Requires single main ditch, $2 \times 3$ feet, I3o feet long. Cost, at 5 cents per foot, is $\$ 6.50$.

56. Class B, 25 per cent. breeding surface. Area, 3.2 acres. No value for hay. Marginal and outlet ditch, 4.50 feet. Cost, \$II.25. 
Shore Marshes.

57. Class B, 50 per cent. breeding surface. Area, 9.7 acres. Produced only a poor sedge grass. Has good primary ditching system which requires cleaning and addition of $\mathrm{I} / \mathrm{I} 50$ lateral system. Footage, 2,800. Cost, $\$ 70.00$.

58. Class $\mathrm{B}$, 50 per cent. breeding surface. Area, I acre. Hay, poor salt grass. Requires single main ditch $\mathrm{I} 30$ feet long. Cost, at $2 \frac{1}{2}$ cents per foot, $\$ 3.25$.

59. Class A. Area, I acre. No hay of any value. Requires 200 feet main ditch, at $2 \mathrm{r} / 2$ cents per foot, $\$ 5.00$.

Note. The Class E area around the edges of the cove into which 58 and 59 drain is mostly wild rice and tidal flat and may be safely disregarded.

6o. Fresh water swamp hole without an outlet. Breeds in wet seasons, more or less. Treatment would be difficult and expensive.

6r. Salt lagoon and marsh without outlet. Marsh is Class D. Area, 2.6 acres. Extreme tides break over the sand beach, fill lagoon and flood the swamp. Drainage only by seepage. Fortunately swamp stands about 3 inches above what appears to be normal level of lagoon so that a ditching system is possible. Central and I/I00 lateral ditches. Footage, 400. Cost, $\$ 10.00$.

62. Fresh water cat-tail swamp. Possibility of intensive breeding of both salt and fresh water species. An outlet might be opened to the Sound but it would be somewhat expensive to drain this area and it is doubtful whether the ditch could be kept open any length of time. The most satisfactory remedy would be to fill the swamp, but this also would be quite expensive. It might be better to watch it carefully for a season to determine fully its importance before doing anything with it.

63. Fresh water cat-tail swamp with small lagoon near lower end. It might prove a serious fresh water and malarial mosquito breeder. Two remedies suggest themselves: (I) to restore the old outlet which leads out at the eastern end, and (2) to dig out the bottom of the lagoon so as to lower the water level enough to drain the swamp. Either would be somewhat expensive and perhaps not worth while. It would take a special and careful engineering estimate to arrive at the cost of either method.

64. Wooded marsh, apparently never much of a breeder and probably can be safely disregarded.

65. Small fresh marsh probably of some local importance. Could be filled for $\$ 100.00$ or less. An outlet could also be opened to the Sound but difficulty would be experienced in keeping it open.

66. Fresh water lagoon near. shore and wooded swamp in rear. Probably a fresh water breeding place of more than casual importance, but a difficult area to treat. An outlet and a tide gate would have to be constructed to drain it and it would also be necessary to place bulkheads on 
each side of outlet channel in order to prevent tidal current from blocking this outlet. It would require a careful and special estimate to arrive at the cost of such measures. Probably it would be well to observe the area carefully over a full season in order to determine its importance.

67. Mill Creek Salt Marsh. Class B, 30 per cent. breeding surface. Area, 60.9 acres, below railroad tracks. Mostly sedge grass of little value for hay. The outlet of this marsh is at present blocked by a wide sand bar. It will be necessary first to remove this bar and second to construct bulkheads on each side of the channel where it passes through the beach to prevent it from again becoming blocked. These bulkheads should be about 100 feet long and constructed of piles and 2 -inch plank. The cost of materials and labor would be about $\$ 2.50 .00$. The cost of removing the bar at a very rough estimate would be $\$ 300.00$. The marsh itself should be ditched I/I50. Footage, I2,700. Cost, \$3I7.50. Total, \$867.50.

Note. The upper portion of 67 is a fresh and wooded marsh but is so remote as to be of almost no consequence and was not specifically examined.

68. Lagoon surrounded by a Class D salt marsh. Upper end is a cattail and 3-square grass marsh. Area of marsh, 19.4 acres. A tide gate in good working condition controls water in lagoon. A I/200 ditching system should be installed with reference to the lagoon. Footage, 4,000. Cost, $\$ 100.00$.

69. Fresh water cat-tail marsh without outlet. Might breed extensively in a wet season. Is now partly filled and work should be continued.

70. Wooded marsh, castual breeder but of no very great importance.

7I. Small marsh area of little importance.

72. Two fresh water lagoons. Might breed slightly along edges and in small marsh areas at upper ends.

73. Series of fresh water pools back of railroad track potential malarial breeders.

74. Small salt marsh along Four-Mile River above railroad track. Apparently of minor importance and not examined specifically.

\section{Summary of Costs for Lyme.}

Fresh' water areas which were estimated separately ... \$ \$00.00

Acreage of salt and brackish marshes, Old Lyme ..... I,393.I

$$
\text { " " " " " " Lyme ....... } 492.5
$$

Total east of Connecticut River .........

Footage of lateral ditch required $\ldots \ldots \ldots \ldots \ldots \ldots \ldots 275,000$
" " larger
“
...................
200 
Cost of cleaning old ditches $\ldots \ldots \ldots \ldots \ldots \ldots \ldots \ldots \ldots \$ 250.00$

" " lateral ditches ...................... $6,850.00$

" " larger ditches ...................... 50.00

" " special work. $\ldots \ldots \ldots \ldots \ldots \ldots \ldots \ldots \ldots \ldots, 700.00$

Total cost for salt marshes east of river ...... $\overline{\$ 7,850.00}$

Cost for Old Lyme only ............. $7,600.00$

Total cost for all areas estimated east of river .. $\overline{\$ 8,650.00}$

Cost for Old Lyme township only ...... 8,400.00

Note. Costs rounded to nearest $\$ 50.00$ for sake of convenience.

Average cost per acre for work on salt marshes in Old

Lyme township .................... \$5.50 


\section{University of}

Connecticut Libraries 
